To overcome these problems schemes have sprung up to lend safety seats to the mothers of newborn children. One of the earliest schemes was organised in Dunedin, New Zealand, in 1981: the parents of every child born in the town's hospital were offered the loan at minimal cost of an infant car seat. ${ }^{4}$ After the initial capital expenditure the scheme became self funding. It was so successful that within three years 300 others had been set up in New Zealand. Loan schemes now exist in many parts of the Western world. In Britain about 50 schemes are known to exist: about half a dozen have been organised by public bodies, and the rest are being run by commercial organisations. The Child Accident Prevention Trust maintains a watching brief over these schemes and is available to offer advice when required. The trust is also conducting a detailed study of eight of the schemes in association with the Transport and Road Research Laboratory.

The loan schemes ensure that mothers have the means to carry their babies home safely from the maternity hospital, setting a safe pattern. They offer the double benefit of both accident prevention through education and practical help and should be available to all families in Britain.

Consultant in Charge,

Accident Centre,

Medway Hospital,

Gillingham,

Kent ME7 9NY

1 Department of Transport. Road accidents Great Britain 1985: the casualty report. London: HMSO, 1986.

2 Hobbs CA, Grattan E, Hobbs JA. Classification of injury severity by length of stay in hospital. London: Department of the Environment, 1979. (Transport and Road Research Laboratory Report No 871.)

3 Farr BN. Safety belts and child restraints-the proportion of cars fited and occupants using them. London: Department of the Environment, 1974. (Transport and Road Research Laboratory Report No 644.)

4 Scherz R. Fatal motor vehicle accidents of child passengers from birth through 4 years of age in Washington State. Pediatrics 1981;68:572-5.

\section{Replacement of the shoulder}

Hip replacement is an everyday occurrence in Britain, and in the past decade knee replacement has become almost as common. But what hope is there of replacing the shoulder for patients with painful arthritis of that joint?

In 1982 Lettin et al showed that it was possible to replace the shoulder with a constrained ball and socket cemented into the humerus and scapula (the Stanmore prosthesis). ${ }^{1}$ Patients gained early relief of pain, but restoration of active movement was inconsistent probably because the prosthesis did not allow the normal descent of the humeral head on abduction. In addition, many of the glenoid components eventually came loose causing increasing pain. Also in 1982 Neer $e t$ al described an unconstrained surface replacement. ${ }^{2}$ Pain relief was as good as with the Lettin prosthesis, but restoration of active movement was better and the glenoid components did not loosen so often. In patients with large rotator cuff ruptures (more than $5 \mathrm{~cm}$ ) pain relief was good, but restoration of active movement was poor. Comparison between the results of these two groups has to be crude because neither used a standard assessment. Standardisations suggested by the American Shoulder and Elbow Surgeons and the European Society for Surgery of the Shoulder and Elbow should allow more accurate comparison soon.

Other surveys have used the Neer prosthesis, ${ }^{3.6}$ and all have achieved poorer results with patients with large cuff ruptures. Barret $e t a l$ also noted that a large cuff rupture was associated with glenoid components loosening more often. ${ }^{5}$ Poppen and Walker showed that the cuff's function is to stabilise the joint while the deltoid muscle moves the arm on the scapula. ${ }^{7}$ A large cuff defect causes this function to be lost, and the joint subluxes on attempted abduction.

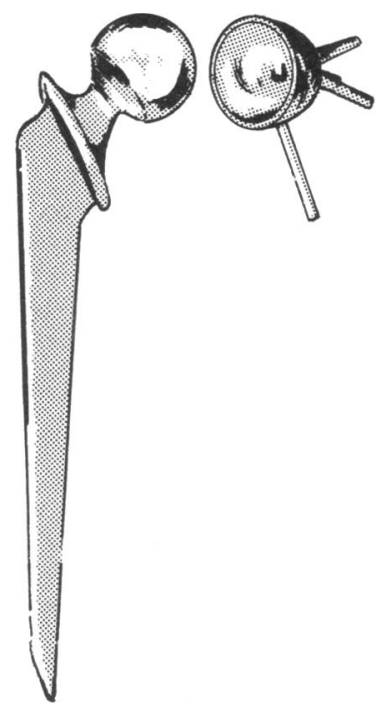

The Stanmore prosthesis.

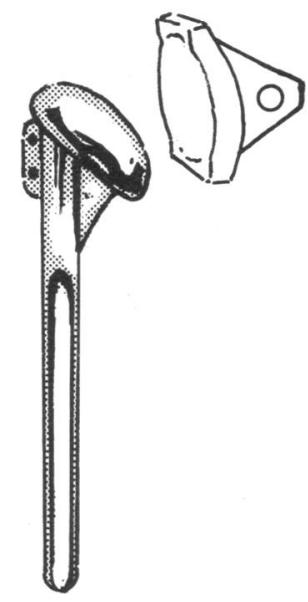

The Neer prosthesis.

Unfortunately it seems unlikely that surgeons will be able to repair the large cuff defects around the prostheses. Attempts have been made to repair the large cuff defects around the Neer prostheses but active movement has not been much improved. ${ }^{2-6}$ Indeed whatever method of repair is used the most important determinant of the outcome is the size of the cuff defect: the bigger the defect the poorer the result. ${ }^{8}$

Repair of the cuff is also unlikely to reduce the rate of loosening of the glenoid component because such loosening is probably caused by eccentric loading of the component by the subluxed humeral component on attempted abduction. It remains to be seen whether the recently developed reinforce- 
ment of the polyethylene glenoid component with a metal keel will reduce late loosening but it is unlikely to do so if eccentric loading is the chief cause.

Since the rotator cuff is so important in determining the outcome every effort, including arthrography and arthroscopy if necessary, ought to be made to determine its state before deciding to replace the joint. Those patients with an intact rotator cuff, or only a small defect, and painful deranged glenohumeral surfaces will get good pain relief and restoration of movement with an unconstrained arthroplasty done by an experienced surgeon. Such procedures are now carried out regularly in Britain. In patients in whom all else has failed the results are gratifying, although not as good as those of hip replacement: patients are usually left with residual stiffness and pain.

Patients with arthritic joints and large cuff ruptures must await the development of a currently impossible combination: a shoulder prosthesis that restores a stable glenohumeral fulcrum in such a way that intolerable loads are not placed on the interface.

Michael Watson

Consultant Orthopaedic Surgeon,

Guy's Hospital,

London SE1 9RT

1 Lettin AWF, Copeland SA, Scales JT. The Stanmore total shoulder replacement. $\mathcal{F}$ Bone foint Surg [Br] 1982;64:47-51.

2 Neer CS II, Watson KC, Stanton FJ. Recent experience in total shoulder replacement. F Bone foin Surg $[A m]$ 1982;64:319-37.

3 Bade HA, Warren RF. Ranawat CS, Inglis AE. In: Bateman JE, Welsh RP, eds. Long term results of Neer total shoulder replacement. Surgery of the shoulder. St Louis: C V Mosby, 1984:294-302. 4 Wilde AH, Borden LS, Brews JJ. Experience with the Neer total shoulder replacement. In Bateman JE, Welsh RP, eds. Surgery of the shoulder. St Louis: C V Mosby, 1984:224-8.

Barrett WB, Franklin JL, Jackins SE, Wyss CR, Matsen FA. Total shoulder arthroplasty. $f$ Bone Barrett WB, Franklin JL, Jackins
foint Surg 1987;69A:865-72.

foint Surg 1987;69A:865-72.
Kelly IG, Foster RS, Fisher WD. Neer shoulder replacement in rheumatoid arthritis. $\mathcal{F}$ Bone foint Kurg $[B r] ~ 1987 ; 69: 723-6$.
Silly IG, Foster RS, Fisher

7 Poppen NK, Walker PS. Forces at the glenohumeral joint in abduction. Clin Orthop 1978;135: $165-70$

8 Watson M. Major rupture of the rotator cuff. F Bone foint Surg [Br] 1985;67:618-24.

\section{Diagnosing Marfan syndrome}

"What value attaches to the diagnosis of a syndrome that can neither be precisely defined nor specifically tested? What is a medical condition in one context could be a social problem, disability, or stigma in a wider social sense ... what happens if it (the diagnosis of Marfan syndrome) appears on your health record when applying for a job, an insurance policy, a mortgage, etc? What use is it to a snared animal to know the name of the trap in which it is caught?" These questions come from the father of a girl with clearcut Marfan syndrome and a son with minor skeletal features of the syndrome. They make us think about what the value is of diagnosing Marfan syndrome.

The Marfan syndrome is a very variable autosomal dominant condition. No single specific diagnostic test for it exists, and the location of the gene awaits discovery. We have no difficulty in making the diagnosis in someone of asthenic build with a funnel chest, arachnodactyly, joint instability, upward dislocations of the lenses, and aortic incompetence, but the full gamut of features is seldom present.

The most important complications of Marfan syndrome are cardiac: mitral incompetence, aortic incompetence, and dissecting aneurysm or rupture of the aorta. ${ }^{1}$ Unfortunately some of those at risk of cardiovascular problems do not have other features of the syndrome in a florid form. ${ }^{2}$ The main reason for diagnosing Marfan syndrome is to offer surveillance for these cardiac problems. ${ }^{2}$ Thus a system is suggested of counting "major" and "minor" criteria of the syndrome in order to decide who should be offered surveillance.

Major criteria include mitral incompetence with a floppy valve, aortic incompetence, a dilated aortic root, dissecting aneurysm of aorta, dislocation of the lens, and a trembling iris. Minor criteria include arachnodactyly, a high arched palate, a funnel chest, an asthenic build, instability of the joints (especially of the ankles), flat feet, scoliosis, spontaneous pneumothorax, a floppy mitral valve (without incompetence), and severe myopia (four dioptres or more). Those who may benefit from cardiac, orthopaedic, and ophthalmic surveillance are identified by having one major with two minor criteria, five minor criteria with a family history of the condition, or seven minor criteria without a family history. All who fulfil these criteria or in whom a suspicion of Marfan syndrome remains should be offered echocardiography, and full reassurance should not be given without it.

Much can be done to slow down, prevent, or treat cardiac complications. $\beta$ Blockers may slow down the rate of aortic dilatation and avoid the other complications. ${ }^{3}$ Replacement of a valve and lagging of the aorta will help later. ${ }^{4}$ Patients with cardiac lesions need three to six monthly surveillance. Those with enough criteria for a diagnosis but no cardiac signs could be checked annually. A pregnant woman with no cardiac signs needs monthly checks from the third month. Another reason for making the diagnosis is to be able to offer genetic counselling. Once the locus of the gene for the Marfan syndrome has been located we will be able to track the gene through known families using closely linked genes or DNA probes. This should make the counselling more accurate, though we will still be unable to predict the likely severity in the offspring of someone known to have the gene. Identifying the gene will allow us to use it as a diagnostic test (even without a family history) and to understand the basic defect.

The main argument against making the diagnosis of Marfan syndrome is that sufferers will have trouble getting insurance and mortgages, but major insurance companies accept someone with Marfan syndrome on normal terms provided there is no cardiovascular problem or appreciable deformity of the chest. This should also apply to applications for jobs and mortgages. The case is strong that doctors should take the trouble to diagnose the Marfan syndrome.

MAURICE SUPER

Consultant Paediatric Geneticist,

Royal Manchester Children's Hospital,

Pendlebury,

Nr Manchester M27 1HA

1 Pyeritz RE. Marfan syndrome. In: Emery AEH, Rimoin DL, eds. Principles and practice of medical genetics. Edinburgh: Churchill Livingstone, 1983. 2 Pyeritz RE, Murphy EA, McKusick VA. Clinical variability in the Marfan syndromes. Birth Defects

3 Halpern B, Char F, Murdoch J, et al. A prospectus on the prevention of aortic rupture in the Marfan syndrome with data on survivorship without treatment. Johns Hopkins Medical fournal 1971;129:123-9.

4 McDonald G, Schaff HV, Pyeritz RE, McKusick VA, Gott VL. Surgical management of patients with Marfan syndrome and dilatation of the ascending aorta. $\mathcal{F}$ Tho:ac Cardiovasc Surg
$1981 ; 81: 180-6$. 